\title{
READERS
}

Journal of Management Info (JMI)

ISSN:2313-3376

www.readersinsight.net/jmi

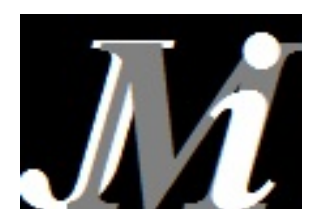

\section{do corporate social responsibility and electronic word-of-mouth influence the perceived quality? Mediating role of brand image}

\author{
Shaista ${ }^{1}$, Mariam$^{2}$, Qasim Ali Nisar ${ }^{3 *}$ \\ ${ }^{1,2,3}$ Department of Management Sciences, University of Sargodha Gujranwala Campus, Pakistan \\ ${ }^{3}$ Department of Management Sciences, University of Sargodha Gujranwala Campus \\ ${ }^{3}$ Othman Yeop Abdullah Graduate School of Business, University Utara Malaysia \\ * Corresponding author: qasimalinisar@yahoo.com
}

\begin{abstract}
The objective of this study is to examine the relationship between corporate social responsibilities, electronic words of mouth and perceived quality by considering the mediating role of brand image. For collecting data, quantitative study was adopted, in which 450 questionnaire were distributed in various universities. Every student belonged to business department. Data was tested through SPSS (Statistical Packages for the Social Science) as well as AMOS (Analysis Movement of Structure). This study shows that there is positive and significant relationship between corporate social responsibility and perceived quality \& electronic word of mouth is highly correlated with perceived quality. Brand image also positively and significantly mediates the relationship among variables. Organizations must understand the importance of corporate social responsibility, electronic words of mouth and other significant factors and try to manage their brand image to influence the perceived quality. If the companies adopt CSR than the brand image will be build up and in this way the perceptions of the consumers will be influenced. Furthermore companies can create awareness regarding their brand through the electronic word of mouth.
\end{abstract}

Keywords: Corporate Social Responsibility, Electronic Word of Mouth, Perceived Quality, Brand Image

\section{ARTICLE INFORMATION}

Received: 25 March 2016

Revised: 25 June 2016

Accepted: 25 August 2016

DOI:

http://dx.doi.org//10.31580/jmi.v11i1.57

\section{Introduction}

Ruiz-Mafe \& Snaz-Blas (2012) proposed that, in the late $20^{\text {th }}$ and $21^{\text {st }}$ centuries CSR has been measured as a comparatively innovative study area because of its reputation. Although its effects were experienced in the late $20^{\text {th }}$ century, in record this conception was deep-rooted as well as extensive.In addition, CSR is considered as important tool which enhanced financial performance and market value through which companies obtain competitive advantage. Moreover, Dacin (1997) identified that, CSR is not influence the companies only but also develops the people trust and their perceptions toward the company's products. In addition to CSR is an important cause which is directly connected with the perceived quality (Campbell, 1999). Similarly people's life style and working style have been modified by internet and information technology. As a result of electronic words of mouth customers can easily convey their observations relating to the organizations. Furthermore ecommerce and electronic words of mouth facilitate the end user. In the current era customers are brand conscious due to their social status. According to Hsieh and Setiono (2004), A fascinating brand image differentiates the firm from its competitors and attracts the consumers to purchase the products. Prospects generally preferred to the branded products due to its fame. Similarly perceived quality of customers also depends upon brand image along with their decision making process regarding the substitutes of brand (Johnson et al., 1995). Additionally, perceived quality is directly associated with the organizations popularity and its brand name. If the organizations will not adopt electronic words of mouth for the purpose of advertisement then they will be fail to compete in the market. Because customers will not be aware about their products. Moreover those corporations who are not socially responsible will be second priority of customers. For the reason that corporations will not be reliable and trustworthy as compare to other CSR firms. In addition, if the brand image of the organization is not good then the customer will switch to other good reputed brand.

In previous studies the researchers ignore CSR and electronic words of mouth but we take these variables as independent in our study and in findings of these studies the researchers have pay less attention on Pakistan so we conducted our study in Pakistan. Moreover we focus on the one targeted group of people (business student) of government universities. The fundamental purpose of this study is scrutinizing affiliation linking Electronic Words of Mouth, Corporate Social Responsibility in addition to Perceived Quality by deliberating the interceding results of Brand Image. If corporations are socially responsible then their brand image will be enhanced and due to this the perceptions of the customers about their products will be positive. Ultimately when organizations use electronic words of mouth to convey their messages about their brands then customers will attract towards their products as well as offers. Due to this their sales and at the end their profit will be increased as through the electronic wordof- mouth messages are spread virally.

The purpose of this study is to examine the relationship between corporate social responsibilities, electronic words of mouth and perceived quality by considering the mediating role of brand image. 


\section{Literature review}

\section{Electronic word-of-mouth (e-wom)}

The Internet has facilitated innovative structure for the purpose of sharing information and point of views of different suppliers and users. According to Duan et al (2008) electronic words of mouth is an online network proposal where the affirmative and unconstructive information circulated among actual buyers as well as prospective consumers. He described that it's an influential alternative to socialize the instructions from one individual to the next. Thurau et al (2004) examined that electronic words of mouth is a declaration about the invention and corporation prepared by possible, authentic along with ex-regulars through the World Wide Web. Furthermore Cheung, et al (2008) proposed that it's a dominant advertising effort in which clients make use of different websites to create awareness regarding products. Moreover electronic words of mouth have exceptional measurability and velocity (Burgee et al., 2009). In addition to Hung and $\mathrm{Li}$ (2007) electronic words of mouth absorbs numerous approaches to provide details in simultaneous manner. Similarly due to high determination of Electronic words of mouth information is available in the form of transcript at the weblogs for a long period of time (Lee et al; 2009). Therefore Electronic Words Of Mouth has durability. It presents a huge range of resources to communicate messages secretly more than that provides a limited liberty (Kiecker \& Cowles, 2001; Gelb \& Sundaram, 2002). (EWOM) Publicize the particulars at a lesser rate and extraordinary momentum (Li \& Zhan, 2011). Additionally Plummer (2007) conducted that due to the enhancement in internet; electronic words of mouth have instigated to present a guarantee for promotion. Cheung et al (2012) enlightened that in the perspective of E-commerce, electronic words of mouth is a foundation for end user sophistications

\section{Corporate social responsibility}

Maloney (2009) proposed that corporate social responsibility as essential responsibility which develops the firm's competitive advantages, financial performance of the company and market value. Carroll(1999,270) identified that, CSR is to make an continuous application for the organization itself and as well as society .similarly, CSR defined in general term, against of the society company have liabilities, but the most specially against to its stakeholders. (Smith, 2003). In addition, Freeman (1984), enlightened the concept of the stakeholder holds most important for shareholders and employees, but it also consumers, suppliers, union, nongovernment organization and Local supervision. More ever, CSR improve the capability to boost the Brand image, increase the customer loyalty and help to improve the culture and staffing, enthusiasm and preservation of staff. In addition, firms have more focus on CSR are more attractive to employees and to gain more competitive edge in attracting more productive applicants (Turban \&Greening, 1997). Sen et al (2006); explored that CSR tricks not necessary for sales growth, but also play a vital role in investment field and employment. Similarly, "CSR is the compulsion of business to give sustainable to economic development, their families, working with employees, group of people and society at large to improve their quality life" (WBCSD,2004). furthermore, Most of the company's preferred to CSR as imperative strategic purpose (Hanna,1993) and seem to spend billion is social responsibility projects (Luo,2006) likewise,. it is accepted that CSR implantation increase sale, market value, enhance brand position, reduce cost such as classified ad and energy consumption, provide a better corporate status and most importantly draw investor attention (Kotler,2004).According to, Friedmanesque view about CSR, shareholders commend the money to managers for the purpose of maximizing the firm value, not only the managers can use money in order to satisfy their desire to make a world well place(Husted \& Salazar,2006; vogel,2005).

\section{Perceived quality}

Perceived quality is a characteristic that recognized in the course of practice and it can't be evaluate. Therefore Trijp et al (1995) enlightened that perceived quality can be scrutinize during the confidential perception of prospect. Consequently perceived quality is considered as vital aspect used for assessment by the customers, and most of the users make a comparison between substitutes in respect of quality including value (Jin and Yong, 2005). According to Johnson et al (1995) perceived quality is a biased decision of excellence relevant toward the anticipation of value. Moreover they signified that these assumptions generally depend upon individual plus others' familiarity, supplementary foundation along with brand status, value as well as promotion. Furthermore perceived quality has direct attention to an objective quality approach that undertake to discover quantifiable more than that assessable facts taking place in already explained principles (Zeithaml et al., 1988). Additionally Davis et al. (2003) identified that perceived quality exactly associated with the organization's prestige from where a product is being assembled. For the reason that perceived quality is clients' awareness concerning with the organization either supremacy of assistance (Aaker, 1991).In accordance with Dodds, et al., (1991), perceived quality is an exchange between affirmation or superiority, ultimate consumer observe in distinction to creation more than that forfeit they recognize as a result of payment. Sweeney and Soutar (2001) categorize perceived quality in three proportions. First of all emotional value which generally consists of sensibility plus passion. Secondly Social value which relates with social self-concept resulting a product. In last Sweeney summed up the perceived quality by exploring the functional value which depends upon cost along with worth of a creation.

\section{Brand image}

According to Hsieh and Setiono (2004), "a charming brand image attract the consumers that will purchase the product and to differentiate the brand from its competitors" Furthermore Keller (1993) identify that brand image is the opinion about the product which is likeness of customer's memory of the product. Aaker (1997), described that Brand is image that the people can be remembered, which make a positive brand and easy to remember by public. (Lee and $\mathrm{Wu}, 2009)$ explained that in several researcher's study at various position of brand image may affect ,brand loyalty and perceived quality ,and if these dimension modify will also effect on overall brand equity's change. Moreover, Oliver(1999), he signified that brand loyalty is an particularly guarantee to repurchase an ideal brand or product again and again in the future, thus causing repeat the same brand purchasing behavior , and in situational pressure and marketing effort ignore the potential affect. Holbrock (2001), Loyalty has divided into two thought, one behavior loyalty and other one attitudinal loyalty. Behavior loyalty is explored that to repurchase the brand by willingness of the average customer. Attitudinal loyalty it is the level of assurance of the regular consumer towards the brand. $\mathrm{He}$ signified that higher brand in attitudinal loyalty direct to great willingness to sacrifice to paying a premium price for valued brand.

\section{CSR and perceived quality}

Mandhachitara \& poolthong investigated that, CSR perceived by the consumer had a significant constructive impact on the service quality perceived by the consumer. Similarly, there is a positive correlation between perceived quality by consumer and CSR studies to be conducted to examine what was the consumer general attitude towards organization that spends in CSR. Dacin (1997) identified that, CSR not only influence the company itself, it persuade the people trust and their mind set towards the company product, and motivation of company has to establish the quality. More ever, CSR is a key factor that is directly associated with the consumer perception of quality (Campbell, 1999).

This paper of studies is to focus only one sector (mobile communication industry) and have to pay the less attention to education sector. We have to be conducted of our studies from the education sector. The more center of the attention of this study on the 
price of the product and almost ignore the quality of the product but our study is to base quality of the product because now a day's people are more conscious about value of the product. In this study almost ignore the electronic word of mouth and brand image but now we have consider these variable like electronic word of mouth as independent variable and brand image as a mediator.

\section{E-WOM and perceived quality}

Gruen et al., (2006) anticipated that there is direct association between electronic words of mouth and perceived quality. Furthermore Electronic words of mouth have considerable dominance over the perceived quality. (Engel et al., 1969; Richins \& RootShaffer, 1988). According to e.g., Day (1971) prospects has a tendency to judge the information from their friends and colleagues. They considered their messages more reliable as compare to salespersons. Because the main focus of the sellers is to enhance their sales (Silverman, 1997). Moreover Bock et al (2012) enlightened that electronic words of mouth have supremacy over the perceived quality because it is believed as a well known structure which is generally associated with the consumers perceptions. Similarly perceived quality of the consumers is strong affected by electronic words of mouth for the reason that perceptions changed due to the electronic words of mouth (Korgaonkar \& Karson; 2007).Additionally Brown and Reingen (1987), explained that words of mouth has a momentous impact over the perceived quality since it relates with the thoughts as well as with the actions of the consumers. Furthermore messages through the electronic words of mouth have a strong effect on the temporary and enduring judgment of the regulars usually linked with the perceived quality (Bone, 1995). On the other hand words of mouth gives an opportunity to the customer to construct the best alternatives in order to enhance perceived quality (Chaniotakis \& Lymperopoulos; 2009).Previous studies collect the data from young adults especially graduates. They target to a specific country. In our study we will use e-questionnaire for the purpose of collecting data.

\section{Mediating role of brand image CSR and brand image}

Arslan \& Zaman (2014) signified that, there is a significant and positive relationship between corporate social responsibility and brand image. According to, Executive of the many association identified that the corporate social responsibility measures play an important role to boost the repute and image of the organization. So corporate social responsibility can influence the brand image in the mind of the customer. In addition, Vitorino \& Cantista (2011) explained that, the policies of the corporate social responsibility are directly and positively associated with brand image of the organization. In this study almost ignore the electronic word of mouth and perceived quality. But we take these variables in our study like electronic word of mouth as an independent variable and perceived quality as an dependent variable and in findings of this research have to pay less attention on Pakistan so we conducted our study in Pakistan

\section{E-WOM and brand image}

According to Jalilvand's (2012) electronic words of mouth is positively correlated with the brand image and has a significant and positive effect on brand image. Moreover in another study it is examined by the researchers that electronic words of mouth have a strong positive influence on brand image (Charo et al., 2105) for the reason that electronic words of mouth enhanced the brand name of a firm. In previous studies the major focus is on the relationship between the electronic words of mouth and purchase intention data is collected through the face to face methodology, moreover they focused on a specific brand. But in our study we will use different methodologies for the collection of data.

\section{Brand image and perceived quality}

Mourad et al., (2010) purported that, brand image is directly effect on the perceived quality. Therefore this study was suggested that brand image have the positive and significant impact on the perceived quality. Similarly, perceived quality domain value to brand in different way, consumer attract with the high quality product and brand are able to differentiate itself from its competitor ,charge finest price against high quality brand. Furthermore, brand image play a vital role in the buyer decision making when the customer find substitute brand. Moreover, an experimentation research have conducted in which discovered that consumer perception of quality and value are significantly affected by brand image (jecoby et al., 1971). Similarly, Kotler (1996) suggested that, to evaluate the perceived quality of the product customer use the brand image. Therefore one research has concluded that there is positive relationship between brand image and perceived quality (Richardson et al., 1996). Previous studies almost ignored the CSR and electronic words of mouth in their studies and current study consider CSR and electronic word of mouth as an independent variable.

\section{Hypotheses}

These hypotheses are described as follows:

H1: There is significant relationship between CSR and perceived quality

H2: There is positive relation between electronic words of mouth and perceived quality

H3: There is significant relation between brand image and perceived quality

H4: There is significant association among e-WOM and Brand Image H5: There is significant and positive association between CSR and brand image

\section{Theoretical framework}

This study includes corporate social respocibility and electronic word of mouth as a predictor variable and perceived quality as a responding variable. On the basis of prior hypothesis researchers develop a theoretical model which expresses the relationship between corporate social responsibility, electronic word of mouth, perceived quality and brand image.

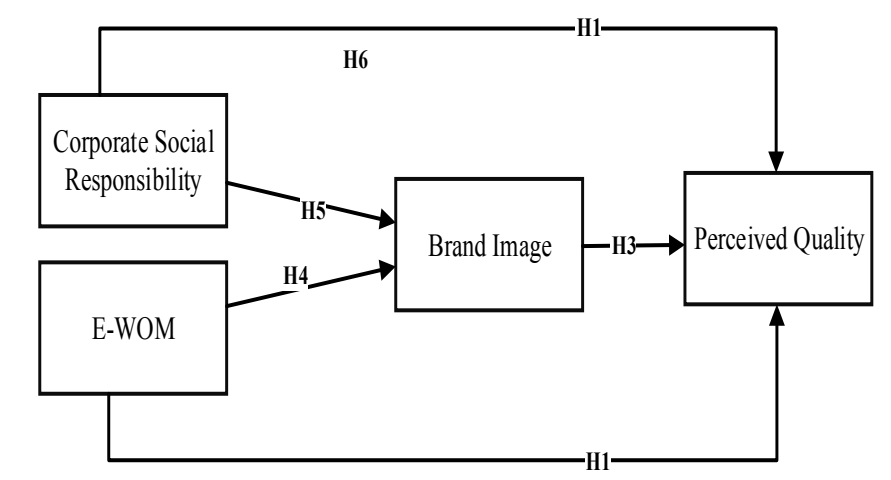

Fig.1. Conceptual Framework

\section{Methodology}

The basic aim of current study is to find the relationship among corporate social responsibility, Electronic word of mouth, Brand image and Perceived quality. The study is deductive in nature. The current study is descriptive and quantative in nature.

\section{Questionnaire design}

Current study used survey method to explore relationship among, corporate social responsibility, Electronic word of mouth, Brand image and Perceived quality. Questionnaire is used in survey. Questionnaires is comprises two sections. First section is related to the personal profile of the respondents including their gender, age group, and educational level, nature of employment and length of employment. Second section deals with the under study variables 
(Electronic words of mouth, corporate social responsibility, Brand image and Perceived quality).

\section{Sampling}

Our population is business students of different universities in Gujranwala. As for as sample size is concerned, Hair et al (2010) described a thumb rule that sample size can be obtained by multiplying the total items in a questionnaire by 10 so by following his methods, sample size for current study is 150 . Data have been collected by applying non probability convenient sampling technique because its most of the studies in social sciences adapted this technique.

\section{Measures}

Survey method was applied to check the relationship among under study variables. Questionnaire used to collect data. All the scales used in the study taken from previous research.

Electronic words of mouth: For the purpose of collect the responses Nina Kaijasilta (2013) adopted 5 item scales regarding electronic word of mouth.

Corporate social responsibility: To measure the corporate social responsibility 13 item scale was adopted.

Brand image: 13 items scale of adopted to collect the responses on the subject of brand image.

Perceived quality: To collect data about perceived quality 6 items scale of (Edwards \& Rothbard's (1999) was used.

\section{Data collection method}

In current study obtained the list of universities from official website that registered. We have distributed 450 questionnaires in different universities. Questionnaire survey method adopted to collect the responses.

\section{Findings}

Table 1: Mean and SD

\begin{tabular}{lccllll}
\multicolumn{1}{l}{ Table 1: Mean and SD } \\
\hline Cons & Mean & SD & $\mathbf{1}$ & $\mathbf{2}$ & $\mathbf{3}$ & $\mathbf{4}$ \\
\hline CSR & 3.91 & .300 & $--(.76)$ & & & \\
EWOM & 4.07 & .415 & $.456^{* *}$ & -- & & \\
BI & 3.98 & .461 & $.318^{* *}$ & $.481^{* *}$ & -- & \\
& & & & & $(.83)$ & \\
PQ & 4.00 & .402 & $.331^{* *}$ & $.337^{* *}$ & $.292^{* *}$ & $--(.82)$ \\
\hline
\end{tabular}

Descriptive statistics, reliability and Pearson correlation between all understudies variables are indicating in the introductory table. Brand image and corporate social responsibility are highly interrelated with each other which are valued at 0.481 . It is representing that brand image and CSR are positively associated with each other with a modest standard deviation. Additional variables which include Electronic word of mouth and perceived quality are also correlated with each other. According to mean values the responses of all variables are presenting affability.

Table 2: Fit Indices for CFA Model

\begin{tabular}{lllllll}
\hline Index of fit & CMIN/DF & P & GFI & AGFI & CFI & RMSEA \\
\hline Value & 2.99 & .07 & .951 & .857 & .948 & .06 \\
\hline
\end{tabular}

Table 2 of Fit Indices Model exemplify the Goodness of Fit Chi Square and other values to decide that the model which is selected is suitable for validity as well as reliability or not. Value of Goodness of Fit Index (GFI) must be more than 0.95, Adjusted Goodness of Fit should be increase than 0.8, CFI should be $>0.95$, Root Mean Square Error of Approximation should be $<0.5$. Therefore, the results value of our model being GFI $=0.951$, AGFI $=0.857, \quad \mathrm{CFI}=0.948$, RMSEA $=0.06$ falls in normal range of acceptance which means that our model is fit for reliability and validity.
To run Confirmatory Factor Analysis the measurement model has been adopted. Table 3 shows the CFA Model which indicates the convergent reliability and discriminant validity of data, this model and its fit indices has been demonstrated.

Table3: Factor Loadings, AVE and CR

\begin{tabular}{|c|c|c|c|}
\hline Items & $\begin{array}{c}\text { Factor } \\
\text { Loadings }\end{array}$ & AVE & CR \\
\hline Corporate Social Responsibilities & & 0.577 & 0.839 \\
\hline CSR1 & .751 & & \\
\hline CSR2 & .648 & & \\
\hline CSR3 & .776 & & \\
\hline CSR4 & .736 & & \\
\hline CSR5 & .767 & & \\
\hline CSR6 & .803 & & \\
\hline CSR7 & .737 & & \\
\hline CSR8 & .708 & & \\
\hline CSR9 & .813 & & \\
\hline CSR10 & .769 & & \\
\hline CSR11 & .865 & & \\
\hline CSR12 & .871 & & \\
\hline CSR13 & .884 & & \\
\hline Electronic Words of Mouth & & 0.567 & 0.774 \\
\hline EWM1 & .877 & & \\
\hline EWM2 & .793 & & \\
\hline EWM3 & .906 & & \\
\hline EWM4 & .782 & & \\
\hline EWM5 & .871 & & \\
\hline Brand Image & & 0.641 & 0.843 \\
\hline BI 1 & .854 & & \\
\hline $\mathrm{BI} 2$ & .874 & & \\
\hline BI 3 & .742 & & \\
\hline BI 4 & .872 & & \\
\hline BI 5 & .733 & & \\
\hline BI 6 & .831 & & \\
\hline BI 7 & .794 & & \\
\hline BI 8 & .902 & & \\
\hline BI 9 & .863 & & \\
\hline BI 10 & .872 & & \\
\hline BI 11 & .795 & & \\
\hline BI 12 & .601 & & \\
\hline BI 13 & .872 & & \\
\hline Perceived Quality & & 0.591 & 0.772 \\
\hline PQ1 & .863 & & \\
\hline PQ2 & .872 & & \\
\hline PQ3 & .916 & & \\
\hline PQ4 & .873 & & \\
\hline PQ5 & .723 & & \\
\hline PQ6 & .840 & & \\
\hline
\end{tabular}

Fornell and Larcker (1981), investigates that there are three steps to check the reliability which involve the factor loading generates value of CFI Model being more than 0.7, the AVE values should be more than 0.5 and the Composite Reliability (CR) value should be more than 0.5 . Hence, the results shown in Table 3 explain that the most of the values of factor loading are greater than 0.7 and significant at 0.001 . Whereas the CR and AVE values are all more than 0.8 and 0.5 .According to results our scale is convergent reliable and proves the discriminant validity, which elaborates that the variables are inconsistent from each other.

\section{Model fit}

\begin{tabular}{lllllll}
\multicolumn{2}{l}{ Table 4: Index of Fit of the Model } \\
\hline Index of fit & CMIN/DF & $\mathbf{P}$ & GFI & AGFI & CFI & RMR \\
\hline Value & 2.99 & .05 & .95 & .876 & .951 & .05 \\
\hline
\end{tabular}


Table 4 represents the fit indices of SEM. Which determine the fitness between the recommended and the existence variance matrix. The first value anticipated by the index of fit beindchisuare (DF) $=2.99$ specifies the fitness of model being used. Therefore, the GFI shows the variance in the model which is 0.95 which is quite fair, AGFI value being 0.876 shows quite a good fit, the CFI value intimates the difference between two models and 0.951 value is good, the RMR value indicating the difference between estimated variance and covariance from observed value being small as 0.05 is good, CFI comparative fit index value 0.951 is considered good. Thus, the result proves that the data is authentic according to the model

Table 5: Structural Model Regression Weights

\begin{tabular}{|c|c|c|c|c|c|c|}
\hline Path & & & Estimate & S.E. & C.R. & $\mathbf{P}$ \\
\hline$P Q$ & $\leftarrow-$ & CSR & .442 & .094 & .056 & .015 \\
\hline$P Q$ & $\leftarrow$ & EWOM & .481 & .088 & 1.25 & .034 \\
\hline $\mathrm{BI}$ & $\leftarrow$ & CSR & .376 & .075 & 2.82 & .025 \\
\hline $\mathrm{BI}$ & $\leftarrow$ & EWOM & .398 & .078 & 1.51 & .018 \\
\hline$P Q$ & $\leftarrow$ & $\mathrm{BI}$ & 354 & 0.76 & 0.66 & .023 \\
\hline
\end{tabular}

CSR = Corporate Social Responsibilities, EWOM=Electronic Words of Mouth, $\mathrm{BI}=$ Brand Image, $\mathrm{PQ}=$ Perceived Quality

For significance level of relationship Table5 indicates the regression weights which is hypothesized in $\mathrm{H} 1, \mathrm{H} 2, \mathrm{H} 3, \mathrm{H} 4$ and $\mathrm{H} 5$. The results shows that all variables have positive and significant and positive relationship therefore all hypothesis $(\mathrm{H} 1, \mathrm{H} 2, \mathrm{H} 3, \mathrm{H} 4$ and $\mathrm{H} 5)$ are supported because $(p<0.05)$. Moreover SEM analysis indicated the positive estimates and S.E in relation with independent variables to dependent variable. So all variables named as corporate social responsibility, electronic word of mouth, perceived quality and brand image are correlated with each other.

\section{SEM Mediation Analysis}

Table 6 depicted the path analysis of given variables and their relationships by using SEM.

Table 6: Path Analysis

\begin{tabular}{lll}
\hline Independent Variables & Effects & Perceived Quality \\
\hline \multirow{2}{*}{$\begin{array}{l}\text { Corporate Social } \\
\text { Responsibilities }\end{array}$} & Direct Effect & $.442^{*}$ \\
& Indirect Effect & $.389^{*}$ \\
& Total Effect & $.498^{*}$ \\
Electronic Words of & Direct Effect & $.481^{*}$ \\
Mouth & Indirect Effect & $.376^{*}$ \\
& Total Effect & $.549^{*}$
\end{tabular}

Mediating variable: Brand Image

Path analysis of variables as well as their relationships is expressed in this table. To explain the directions of relationship all the values of direct and indirect affect has been provided. Greater value indirect effect shows the strong mediation effect of brand image between corporate social responsibility, electronic word of mouth and perceived quality. The value of total effect is also high which indicates that brand image is a momentous mediator among corporate social responsibility, electronic word of mouth and perceived quality.

\section{Conclusion and discussion}

The purpose of this paper is to investigate the relationship between corporate social responsibility, electronic words of mouth, brand image as well as perceived quality. To explore the effect of CSR \& electronic words of mouth, we propose our study and then theoretically test it through questionnaire survey from existing universities. The reason to adopt survey method is to accumulate quantitative data using descriptive statistics. According to Babbie, (2007) three steps include in survey, the first one is sample selection of the respondents, formation of the standardized questionnaire and the last one allocation of the questionnaire among the respondents. Moreover, adoption of survey method consist of two important reasons, the first is that to compute the characteristics of the huge population and the second one is that it is considered an important tool to observe population directly. Therefore this research method is more suitable. Findings show that there is positive and significant relationship between CSR and Perceived quality. This study supported by previous studies. Furthermore CSR is considered an important tool which is directly linked with the perceive quality (Campbell, 1999).because CSR is not affect the company but it also convinced the peoples trust as well as their perceptions towards a company's product. Similarly Korgaonkar \& Karson (2007) enlightened that electronic word of mouth have strong effect on perceived quality because perceptions of the people influenced by EWOM. Additionally messages by electronic words of mouth strongly influence the decisions of regular consumers as well as their actions (Bone, 1995). In addition to Corporate social responsibility is directly and positively correlated with brand image (vitorino \& cantista;2011).Besides this executives of many organizations suggested that Corporate social responsibility plays a vital role to builds up the image of brands (Arslan \& Zaman 2014).Likewise Charo, et al; (2105) explained that electronic word of mouth has a significant impact on brand image furthermore electronic words of mouth strongly linked with the brand image (Jalilvand's 2012).moreover perceptions of the consumers positively influenced by brand image(jecoby et al ;1971). Richardson et al ; (1996) summed up that there is strong and positive connection among brand image and perceived quality.

\section{Limitations and future directions}

The limitation of this study is that quantitative research method is used in this study to influence the variables, all the relationships depends upon the previous studies. Moreover quantitative \& quantitative studies can be combined to get an excellent model. A further limitation is that data is being collected through questionnaire method only which lacks validity because only a limited amount of information can be obtained without any explanation. Another limitation is that sample size is only 450 which can be improved. Furthermore the researchers can target more than one sector. Longitudinal study can be applied. Likewise this study can be appropriate internationally.

\section{References}

Aaker, D.A. (1991). Managing Brand Equity: Capitalizing on Value of a Brand Name. The Free Press, New York, and ISBN: 0-02-900101-3, pp: 299.

Aaker, J. L. (1997). Dimensions of Brand Personality. Journal of Marketing Research, 34(3),347-356.http://dx.doi.org/10.2307/3151897

Abdullah Alhaddad (2105). Perceived Quality, Brand Image and Brand Trust as Determinants of Brand Loyalty. Journal of Research in Business and Management Volume 3 Issue 4(2015) pp: 01-08 ISSN (Online): 23473002

Bock, G. W., Lee, J., Kuan, H. H. \& Kim, J. H. (2012). The Progression of Online Trust in the Multi-Channel Retailer Context and the Role of Product Uncertainty. Decision Support Systems, 53, 97-107.

Bone, P. F. (1995). Word-of-mouth effects on short-term and long-term product judgment. Journal of Business Research, 32 (3), 213-23.

Brown, J. J. \& Reingen, P. H. (1987). Social Ties and Word-of-Mouth Referral Behavior. Journal of Consumer Research, 14, 350-362.

CarrollA.B.(1999).Corporate Social Responsibility: Evolution of a Definitional Construct, Business Society(383),(268)-295

Chaniotakis, I. E. \& Lymperopoulos, C. (2009). Service quality effect on satisfaction and word of mouth in the health care industry. Managing Service Quality, 19(2), 229-242.

Chen, C. and Tseng, W. (2010), "Exploring Customer based Airline Brand Equity: Evidence from Taiwan", National Science Council (NSC), Taiwan, pp.24-34.

Cheung, C.M.K., and D.R. Thadani.(2012). The Impact of Electronic Wordof-Mouth Communication: A Literature Analysis and Integrative Model," Decision Support Systems, Vol. 54, No. 1:461-470.

Cheung, C.M.K., Lee, M.K.O., \& Rabjohn, N. (2008). The impact of electronic word-of-mouth. The adoption of online opinions in online customer communities. Internet Research, 18(3), 229-247. 
Davis, Aquilano and Chase. (2003). Fundamentals of Operations Management. 4th Edn., McGraw- Hill/Irwin, ISBN: 0-07-297541-5, pp: 1.

DeShields, J., Oscar, W., Kara, A., \& Kaynak, E. (2005). Determinants of Business Student Satisfaction and Retention in Higher Education: Applying Herzberg's Two-Factor Theory. International Journal of $\begin{array}{llr}\text { Educational } & \text { Management, } & 19(2),\end{array}$ http://dx.doi.org/10.1108/095135405105824

Duana, W., Gub, B., \& Whinston, A.B. (2008). Do online reviews matter? - an empirical investigation of panel data. Decision Support Systems, 45(3), 1007-1016.

Engel, J.F., Kegerris, R.J., and Blackwell, R.D. (1969). Word of Mouth Communication by the Innovator," Journal of Marketing, 33, 15-19

Freeman, E. (1984).Strategic Management: A Stakeholder Approach, University of Minnesota, And London: Pitman Publishing

Gruen, T. W., Osmonbekov, T., \& Czaplewski, A. J. (2006). EWOM: The impact of customer-to-customer online know-how exchange on customer value and loyalty. Journal of Business Research, 59(4), 449-456

Hennig-Thurau, T., Gwinner, K.P., Walsh, G., \& Gremle, D.D. (2004). Electronic http://dx.doi.org/10.2501/JAR-51-1-239-257

Hung, K., Stella, H., \& Li, Y. Y. (2007). The influence of e WOM on virtual consumer communities: Social Capital, consumer learning, and behavioral outcomes. Journal of Advertising Research, 47(4), 485-495.

J. C. Sweeny and G. N. Soutar. (2001). Consumer-perceived value: The Development of a Multiple Item Scale. Journal of Retailing, vol. 77, no. 2, (2001), pp. 203-220.

Jin, B. and G.S. Yong, 2005. Integrating effect of consumer perception factors in predicting private brand purchase in a Korean discount store context. Consumer Market, 22: 62-71. DOI: 10.1108/07363760510589226

Johnson, Michael D., Eugene W. Anderson, and Claes Fornell (1995). Rational and Adaptive Performance Expectations in a Customer Satisfaction Framework. Journal of Consumer Research, 21(4), 695-707.

Keller, K. L. (1993). Conceptualizing, Measuring and Managing CustomerBased Brand Equity. Journal of Marketing, 57(1), 122.http://dx.doi.org/10.2307/1252054

Kiecker, P., \& Cowles, D.L. (2001). Interpersonal communication and personal influence on the internet: A framework for examining online word-of-mouth. Journal of Euro marketing, 11(2), 71-88.

Korgaonkar, P. and Karson, E. (2007). The Influence of Perceived Product Risk on Consumers' e-Tailer Shopping Preference. Journal of Business Psychology, 22, 55-64

Lee, H. M., Lee, C. C., \& Wu, C. C. (2009). Brand image strategy affects brand equity after M\&A. European Journal of Marketing, 45(7/8), 10911111

Li, J., \& Zhan, L. J. (2011). Online persuasion: How the written word drives WOM evidence fromconsumer-generated product reviews. Journal of Advertising Research, 51(1), 239-257.
Luo, X., \& Bhattacharya, C. B. (2006). Corporate Social Responsibility, Customer Satisfaction, and Market Value. Journal of Marketing, 70(4), 118.

Oude Ophuis, Peter A.M. \& Van Trijp, Hans C.M.(1995). Perceived Quality: A market driven and consumer oriented approach. Food Quality and Preference 6, pp. 177-183

Plummer, J. T. (2007). Word of mouth: A new advertising discipline? Journal of Advertising $\quad$ Research, 47(4), 385-386. http://dx.doi.org/10.2501/S0021849907070390

Richins, M. and Root-Shaffer, T. (1988) "The Role of Evolvement and Opinion Leadership in Consumer Word-of-Mouth: an Implicit Model Made Explicit," Advances in Consumer Research, 15, 32-36.

Schiffman, L. G., \& Kanuk, L. L. (2010). Consumer Behavior. New Jersey: Pearson-Prentice Hall.

Silverman, G. (1997) "How to Harness the Awesome Power of Word of Mouth", Direct Marketing, November, 32-37.

Smith, N.C. (2003).Corporate Social Responsibility: Whether or How? California Management Review, 45(4), 52-76.

Turban, D. and Greening, D. (1997). Corporate social p performance and organizational attractiveness to prospective employees, Academy of Management Journal (403), 658672

W. B. Dodds, K. B. Monroe and D. J. Grewal. (1991). Effects of Price, Brand and Store Information on Buyers' Product Evaluations. Journal of Marketing Research, vol. 28, pp. 307-319

Wagner, J., \& Hanna, S. (1983). The Effectiveness of Family Life Cycle Variables in Consumer Expenditure Research. The Journal of Consumer Research, 10(3), 281-291.

Hsieh, M. H., Pan, S. L., \& Setiono, R. (2004). Product-, corporate-, and country image dimensions and purchase behavior: A multicounty analysis. Journal of academy of Marketing Science, 32(3), 251-270 Word-of-mouth via consumer-opinion platforms: What motivates consumers to articulate themselves on the Internet? Journal of Interactive Marketing, 18(1), 3852.

Yu, C., Li, H., \& Dong, Y. (2013). Empirical Study on Influence Factors and Moderating Effect of Continual Use Behaviors of Antivirus Software.Science and Technology Management Research No. 5, 178192

Zeithaml, Valarie A. (1988). Consumer Perceptions of Price, Quality and value: A

Means-End Model and Synthesis of Evidence. Journal of Marketing, Vol. 50 pp. 2-22 